\title{
PENINGKATAN KEMAMPUAN GURU DABIN GUGUS PUTRA SERANG \\ IV WONOSEGORO - BOYOLALI DALAM MEMANFAATKAN \\ LINGKUNGAN SEKOLAH SEBAGAI SUMBER BELAJAR \\ MELALUI DISKUSI KELOMPOK KERJA GURU
}

\author{
Parwanto \\ parwanto63@gmail.com \\ UPTD Dikdas dan LS Kecamatan Wonosegoro - Boyolali
}

\begin{abstract}
ABSTRAK
Tujuan penelitian ini adalah untuk meningkatkan kemampuan guru dalam memanfaatkan lingkungan sekolah sebagai sumber belajar melalui diskusi Kelompok Kerja Guru (KKG) di Dabin Gugus Putra Serang IV Kecamatan Wonosegoro. Jenis penelitian yang digunakan dalam penelitian ini adalah penelitian tindakan kelas, yang terdiri dari dua siklus. Masing-masing siklus terdiri atas tahapan perencanaan tindakan, pelaksanaan tindakan, observasi, dan refleksi. Teknik pengumpulan data menggunakan instrumen obeservasi, instrumen penilaian rencana pelaksanaan pembelajaran dan instrumen penilaian pelaksanaan pembelajaran. Analisis data yang digunakan adalah teknik analisis deskriptif komparatif. Data kuantitatif yang diperoleh di deskripsikan dalam bentuk kata-kata atau penjelasan. Analisis data dilakukan dengan menggunakan analisis deskriptif komparatif yaitu membandingkan hasil siklus 1, dan siklus 2. Hasil penelitian menunjukkan temuan bahwa Diskusi Kelompok Kerja Guru (KKG) dapat: a) meningkakan kemampuan guru dalam penyusunan RPP di Dabin Putra Serang IV, Kecamatan Wonosegoro, Kabupaten Boyolali sebesar 3,70\% b) meningkatkan kemampuan guru dalam pelaksanaan pembelajaran di Dabin Putra Serang IV, Kecamatan Wonosegoro, Kabupaten Boyolali meningkat sebesar 3,67\%.
\end{abstract}

Kata kunci: Kemampuan guru dalam memanfaatkan lingkungan sekolah sebagai sumber belajar, dkskusi kelompok kerja guru

\section{PENDAHULUAN}

Kurikulum Tingkat Satuan Pendidikan (KTSP) menekankan pada pembelajaran yang berpusat pada peserta didik (student centered). Guru sebagai fasilitator harus mampu memilih dan menerapkan model, metode atau setrategi pembelajaran yang sesuai dengan karakteristik materi sehingga pembelajaran menjadi variatif, kreatif, menyenangkan serta dapat mengembangkan daya nalar peserta didik secara optimal. Salah satu strategi pembelajaran yang dapat mengembangkan kreativitas, motivasi dan partisipasi peserta didik dalam pembelajaran adalah dengan memanfaatkan lingkungan sekolah sebagai sumber belajar. 
Peningkatan Kemampuan Guru Dabin Gugus Putra Serang IV Wonosegoro - Boyolali dalam Memanfaatkan Lingkungan Sekolah Sebagai Sumber Belajar Melalui Diskusi Kelompok Kerja Guru (Parwanto)

KTSP sebagai upaya mendekatkan aktivitas belajar peserta didik pada berbagai fakta kehidupan sehari-hari di sekitar lingkungan peserta didik. Pemanfaatan lingkungan sekolah sebagai sumber belajar menjadi alternatif strategi pembelajaran untuk memberikan kedekatan teoritis dan praktis bagi pengembangan hasil belajar peserta didik secara optimal. Ekowati (2001) mengatakan, pemanfaatan lingkungan sekolah sebagai sumber belajar merupakan bentuk pembelajaran yang berpihak pada pembelajaran melalui penggalian dan penemuan (experiencing) serta keterkaitan (relating) antara materi pelajaran dengan konteks pengalaman kehidupan nyata melalui kegiatan proyek.

Kenyataannya tujuan pembelajaran agar siswa belajar melalui pengalaman langsung dari lingkungan sekolah masih jauh dari harapan. Hasil observasi peneliti dan teman sejawat yang dilakukan di lingkungan Dabin Gugus Putra Serang IV Wonosegoro-Boyolali menemukan permasalahan bahwa pembelajaran guru sering menyajikan pelajaran di dalam kelas walaupun materi berkaitan dengan lingkungan sekolah. Hasil wawancara yang dilakukan peneliti dengan kepala sekolah di lingkungan Dabin Gugus Putra Serang IV, sebagian besar guru belum mengajak peserta didik belajar di luar kelas dengan alasan susah mengawasi. Selain itu ada beberapa guru belum bisa dan belum tahu bagaimana memanfaatkan lingkungan sekolah sebagai sumber belajar. Melihat kondisi seperti ini, peneliti berupaya melakukan perbaikan pembelajaran dalam rangka meningkatkan kemampuan guru dalam memanfaatkan lingkungan sekolah sebagai sumber belajar. Kajian pustaka yang dilakukan peneliti menemukan informasi berbagai strategi pembelajaran yang sangat potensial untuk meningkatkan kemampuan guru dalam memanfaatkan lingkungan sekolah sebagai sumber belajar.

Berdasarkan latar belakang seperti tersebut di atas, permasalahan penelitian yang akan dipecahkan dalam PTS ini adalah apakah kemampuan guru dalam memanfaatkan lingkungan sekolah sebagai sumber belajar dapat ditingkatkan melalui diskusi KKG dan apakah diskusi KKG terhadap peningkatan kemampuan guru dalam memanfaatkan lingkungan sekolah sebagai sumber belajar.

\section{KAJIAN PUSTAKA}

\section{Hakikat Kemampuan Guru}

Guru adalah orang yang professional dalam menjalankan tugasnya. Menurut Undang-Undang Nomor 14 Tahun 2005 menyebutkan bahwa guru mempunyai kedudukan sebagai tenaga profesional yang berfungsi untuk meningkatkan mutu pendidikan nasional. Sedangkan Sagala Syaiful (2009:209) menjelaskan bahwa kompetensi merupakan kemampuan yang harus dimiliki oleh guru dalam menjalankan tugas dengan profesional. 
Dari pendapat diatas dapat disimpulkan bahwa guru merupakan tenaga profesional yang mempunyai kemampuan dalam menjalankan tugasnya dalam rangka peningkatan mutu pendidikan nasional.

Peraturan Pemerintah RI No 19 Tahun 2005 mengenai Standar Nasional Pendidikan menyebutkan bahwa guru memiliki 4 kompetensi meliputi: 1) kompetensi pedagogik, yakni kemampuan mengelola pembelajaran yang meliputi pemahaman terhadap peserta didik, perancangan dan pelaksanaan pembelajaran, evaluasi hasil belajar, dan pengembangan peserta didik untuk mengaktualisasikan berbagai potensi yang dimilikinya. 2) kompetensi kepribadian, yakni kemampuan kepribadian yang mantap, stabil, dewasa, arif, dan berwibawa, mampu menjadi teladan bagi peserta didik, serta berakhlak mulia. 3) kompetensi profesional, yakni kemampuan penguasaan materi pembelajaran secara luas dan mendalam untuk membimbing peserta didik dan 4) kompetensi sosial, yakni kemampuan pendidik sebagai bagian dari masyarakat untuk berkomunikasi dan bergaul secara efektif dengan peserta didik, sesama pendidik, tenaga kependidikan, orangtua/wali peserta didik, dan masyarakat sekitar.

Dari empat kompetensi tersebut, kompetensi pedagogik menjadi salah satu kemampuan yang perlu dikembangkan karena sesuai dengan kebutuhan seperti telah dipaparkan pada bagian latar belakang masalah.

Kompetensi pedagogik adalah kemampuan guru dalam mengelola pembelajaran yang meliputi pemahaman terhadap peserta didik, perancangan dan pelaksanaan pembelajaran, evaluasi hasil belajar, dan pengembangan peserta didik untuk mengaktualisasikan berbagai potensi yang dimilikinya (Undang-Undang Nomor 14 Tahun 2005). Terkait dengan standar kompetensi pedagogik, Dirjen PMPTK (2012:42) menyebutkan bahwa kompetensi inti yang harus dimiliki oleh seorang guru dengan pedoman pelaksanaan penilaian kinerja guru meliputi: 1) mengenal karakteristik peserta didik, 2) penguasai teori belajar dan prinsip-prinsip pembelajaran yang mendidik, 3) pengembangan kurikulum, 4) kegiatan pembelajaran yang mendidik, 5) pengembangan potensi peserta didik, 6) komunikasi dengan peserta didik, 7) penilaian dan evaluasi.

Lebih lanjut Dirjen PMPTK (2012:71) menyebutkan pedoman pengukuran kompetensi pedagogik yaitu: 1) menyusun alat penilaian sesuai dengan tujuan pembelajaran (RPP), 2) melaksanakan penilaian, 3) menganalisa hasil penilaian, 4) memanfaatkan masukan dari peserta didik dan merefleksikan, 5) memanfaatkan hasil penilaian sebagai penyusunan rancangan pembelajaran selanjutnya.

Berdasarkan uraian tentang definisi kemampuan guru, nampak bahwa kemampuan guru hakikatnya merupakan sebuah kemampuan, pengetahuan, dan keterampilan dalam menjalankan tugas keprofesiannya untuk menciptakan mutu pembelajaran. 
Peningkatan Kemampuan Guru Dabin Gugus Putra Serang IV Wonosegoro - Boyolali dalam Memanfaatkan Lingkungan Sekolah Sebagai Sumber Belajar Melalui Diskusi Kelompok Kerja Guru (Parwanto)

\section{Pemanfaatan Lingkungan Sekolah sebagai Sumber Belajar}

Sumber belajar masyarakat dapat digunakan untuk kepentingan proses pembelajaran sains, ilmu sosial dan yang lainnya yaitu melalui survei wilayah. Survei wilayah peserta didik akan menemukan sumber belajar di masyarakat sehingga mampu menumbuhkan motivasi untuk memperkaya nilai-nilai hasil belajar guna dapat meningkatkan pemahaman dan peningkatan materi pelajaran (Sarman, 2005:3).

Douglas dan Mill dikutip oleh Rusyan (2001:152) nilai-nilai kegunaan sumber belajar masyarakat adalah (1) menghubungkan kurikulum dengan kegiatankegiatan masyarakat akan mengembangkan kesadaran dan kepekaan terhadap masalah sosial; (2) menggunakan minat-minat pribadi peserta didik akan menyebabkan belajar lebih bermakna baginya; (3) mempelajari kondisi-kondisi masyarakat merupakan latihan berpikir ilmiah (scientif methode); (4) mempelajari masyarakat akan memperkuat dan memperkaya kurikulum melalui pelaksanaan praktis di dalam situasi sesungguhnya; (5) peserta didik memperoleh pengalaman langsung yang kongkrit, realistis dan verbalisme.

Pemanfaatan lingkungan sekolah sebagai sumber belajar mengarahkan anak pada peristiwa atau keadaan yang sebenarnya atau keadaan yang alami sehingga lebih nyata, lebih faktual dan kebenarannya lebih dapat dipertanggungjawabkan. Badru Zaman, dkk (2005) menyebutkan bahwa manfaat nyata yang diperoleh dari pemanfaatan lingkungan adalah (1) menyediakan berbagai hal yang dapat dipelajari anak, (2) memungkinkan terjadinya proses belajar yang lebih bermakna (meaningful learning), (3) memungkinkan terjadinya proses pembentukan kepribadian anak, (4) kegiatan belajar akan lebih menarik bagi anak, dan (5) menumbuhkan aktivitas belajar anak (learning aktivities).

\section{Diskusi Kelompok Kerja Guru (KKG)}

KKG merupakan bentuk kegiatan yang beranggotakan guru-guru kelas, dengan tujuan untuk meningkatkan kemampuan dan kompetensi mereka sesuai kelas yang dipegang. Bentuk kegiatan KKG bisa berupa diklat, simulasi, diskusi atau yang lainnya.

Dari berbagai bentuk kegiatan KKG, diskusi kelompok akan diterapkan dalam penelitian ini. Diskusi kelompok merupakan suatu kegiatan belajar yang dilakukan secara bersama-sama. Diskusi kelompok didasarkan pada pemecahan persoalan secara bersama-sama. Artinya setiap anggota turut memberikan sumbangan pemikiran dan pendapat dalam memecahkan persoalan tersebut. Tabrani dan Daryani dalam Kasianto (2004) menjelaskan bahwa diskusi kelompok adalah suatu kegiatan belajar untuk memecahkan persoalan secara bersama-sama, sehingga memperoleh hasil yang lebih baik (Tabrani dan Daryani dalam Kasianto, 2004). 
Berdasarkan uraian di atas, dapat disimpulkan bahwa diskusi kelompok adalah suatu proses usaha yang dilakukan individu untuk memperoleh perubahan tingkah laku sebagai pengalaman individu dalam interaksinya dengan lingkungan yang dilakukan secara bersama-sama atau berkelompok.

Ischak SW dan Warji R. (dalam Kasianto, 2004) menyebutkan langkahlangkah pelaksanaan diskusi kelompok, yaitu (a) memlilih teman yang cocok untuk bergabung dalam belajar kelompok. Jumlah setiap kelompok terdiri dari 5 hingga 7 orang. (b) menetapkan pemimpin yang akan memimpin jalankan diskusi atau belajar kelompok. (c) menyelesaikan persoalan satu persatu dengan memberi kesempatan kepada anggota untuk mengajukan pendapatnya.

Dari uraian di atas, maka di dalam pelaksanaan diskusi kelompok perlu diperhatikan pembentukan kelompok, penetapan pimpinan kelompok, penetapan masalah yang akan dibahas dan pencatatan kesimpulan hasil diskusi kelompok.

\section{Peningkatan Kemampuan Guru Dalam Memanfaatkan Lingkungan Sekolah Sebagai Sumber Belajar Melalui Diskusi di Forum KKG}

Peningkatkan mutu guru dalam pemanfaatan lingkungan sekolah sebagai sumber belajar perlu dilakukan secara terprogram, terstruktur dan berkelanjutan melalui pembinaan profesional oleh kepala sekolah dan pengawas sekolah sehingga dapat mengetahui permasalah yang dihadapi oleh guru dan memecahkan permasalahan tersebut melalui diskusi pada forum KKG. Esensi diskusi pada forum KKG sebagai wadah kegiatan belajar guru-guru untuk mendiskusikan persoalan yang dihadapi dan mencari solusi pemecahan masalah.

Sedangkan yang dimaksud dengan peningkatan kemampuan guru dalam memanfaatkan lingkungan sekolah sebagai sumber belajar melalui diskusi KKG adalah kegiatan belajar para guru dalam mengkaitkan antara materi pelajaran dengan lingkungan sekolah yang dapat memungkinkan siswa belajar langsung dari lingkungan sekolah sehingga siswa dapat mengintegrasikan materi pelajaran dengan pengetahuan dan keterampilan.

Kegiatan diskusi KKG dalam rangka peningkatan kemampuan guru memanfaatkan lingkungan sekolah sebagai sumber belajar melalui langkah-langkah: 1) membentuk kelompok, setiap kelompok terdiri dari 5 orang. 2) menetapkan pemimpin dalam kelompok. 3) masing-masing guru menyusun Rencana Pelaksanaan Pembelajaran (RPP) yang berkaitan dengan pemanfaatan lingkungan sekolah sebagai sumber belajar kemudian melakukan peer teaching sesuai dengan RPP yang telah dibuat.

Dengan langkah-langkah kegiatan seperti diuraikan dalam kerangka pikir di atas, tujuan dari diskusi dalam forum KKG akan tercapai. Tujuan tersebut adalah 
Peningkatan Kemampuan Guru Dabin Gugus Putra Serang IV Wonosegoro - Boyolali dalam Memanfaatkan Lingkungan Sekolah Sebagai Sumber Belajar Melalui Diskusi Kelompok Kerja Guru (Parwanto)

meningkatnya kemampuan guru dalam memanfaatkan lingkungan sekolah sebagai sumber belajar.

\section{METODE PENELITIAN}

Penelitian Tindakan Sekolah (PTS) ini dilakukan pada forum KKG dabin Putra Serang IV, Kecamatan Wonosegoro-Boyolali tahun pelajaran 2014/2015. Pelaksanaan penelitian tindakan sekolah ini dilakukan melalui tahapan penyusunan proposal penelitian, penyusunan instrumen, pelaksanaan tindakan dalam rangka pengumpulan data, analisis data dan pembahasan hasil penelitian serta penyusunan laporan PTS. Waktu pelaksanaan setiap tahap PTS adalah sebagai berikut: 1) penyusunan proposal penelitian dilakukan pada September tahun 2014; 2) Penyusunan instrumen PTS dilakukan pada September minggu ke -3 tahun 2014; 3) Pelaksanaan tindakan siklus 1 dilakukan pada Oktober minggu ke-1 tahun 2014. Siklus 2 dilakukan pada November minggu ke-1 tahun 2014. Analisis data dan pembahasan hasil penelitian serta penyusunan laporan PTS dilakukan pada bulan Desember minggu ke-1 sampai minggu ke-4.

Populasi penelitian dalam penelitian tindakan sekolah ini adalah guru kelas I sampai VI yang berjumlah 30. Sedangkan sampel dalam penelitiaan ini berjumlah 10 orang yang berasal dari 5 SD yang berbeda namun masih dalam satu Dabin. Sampel penelitian ini ditentukan oleh peneliti dengan alasan agar pengamatan dan penilaian lebih efektif dan terfokus karena tidak terlalu banyak yang diamati dan yang dinilai. Sumber data primer berasal dari hasil pengukuran variabel penelitian tindakan sekolah berikut: 1) skor kemampuan guru dalam penyusunan rencana pembelajaran, 2) skor kemampuan guru dalam pelaksanaan pembelajaran.

Teknik pengumpulan data dalam penelitian ini menggunakan teknik tes dan non tes. Instrumen non tes berupa: 1) instrumen kemampuan guru dalam penyusunan rencana pembelajaran, 2) instrumen kemampuan guru dalam pelaksanaan pembelajaran. Tiap instrumen penilaian terdapat 5 kualifikasi penilaian yaitu 1, 2, 3, 4 dan 5. Setiap skor yang diperoleh kemudian dibagi dengan skor maksimal dan dikalikan dengan 100 atau $\mathrm{N}=\frac{\text { skor yang diperoleh }}{\text { skor maksimal }} \mathrm{X} 100$. Adapun kriteria penilaian yaitu: Baik Sekali berada di skor 90 sampai 100, Baik berada pada skor 80 sampai 89, Cukup berada pada skor 65 sampai 79, Kurang berada pada skor 55 sampai 64 sedangkan Sangat Kurang berada pada skor kurang dari 54.

Analisis data yang digunakan adalah teknik analisis deskriptif komparatif. Data kuantitatif yang diperoleh di deskripsikan dalam bentuk kata-kata atau penjelasan. Baik data yang diperoleh dari hasil penyusunan RPP dan pelaksanaan pembelajaran. Selanjutkan dilakukan komparasi data setiap siklus untuk memastikan ada tidaknya peningkatan kemampuan guru dalam memanfaatkan lingkungan sekolah sebagai sumber belajar. 


\section{HASIL DAN PEMBAHASAN}

Setelah melakukan analisa terhadap data yang diperoleh dari dua siklus yang dilaksanakan, maka dapat disimpulkan bahwa penggunaan strategi diskusi dalam forum $\mathrm{KKG}$ menunjukkan peningkatan kemampuan guru dalam memanfaatkan lingkungan sekolah sebagai sumber belajar. Tabel 1 merangkum komparasi tingkat kemampuan guru dalam penyusunan RPP dalam memamfaatkan lingkungan sekolah sebagai sumber belajar, siklus 1 sampai siklus 2 .

\section{Tabel 1}

\section{Komparasi Tingkat Kemampuan Guru Dalam Penyusunan RPP}

\begin{tabular}{|l|c|c|}
\hline \multirow{2}{*}{ Pembelajaran } & \multicolumn{2}{|c|}{ Tingkat kemampuan guru dalam penyusunan RPP } \\
\cline { 2 - 3 } & Mean & \% Kenaikan \\
\hline Siklus 1 & 78,80 & - \\
\hline Siklus 2 & 82,50 & 3,70 \\
\hline
\end{tabular}

Dari data dalam Tabel diatas, diperoleh temuan: a) pada siklus 1, rata-rata tingkat kemampuan guru dalam penyusunan RPP mencapai 78,80. b) pada siklus 2, rata-rata kemampuan guru dalam penyusunan RPP mencapai 82,50. Data ini menunjukkan Capaian ini menunjukkan peningkatan kemampuan guru dalam penyusunan RPP sebesar 3,70\%.

Kenaikan tingkat kemampuan guru dalam pelaksanaan pembelajaran. dirangkum dalam tabel 2 berikut.

\section{Tabel 2}

\section{Komparasi Tingkat Kemampuan Guru Dalam Pelaksanaan Pembelajaran}

\begin{tabular}{|l|c|c|}
\hline \multirow{2}{*}{ Pembelajaran } & \multicolumn{2}{|c|}{$\begin{array}{c}\text { Tingkat kemampuan guru dalam pelaksanaan } \\
\text { pembelajaran }\end{array}$} \\
\cline { 2 - 3 } & Mean & \% Kenaikan \\
\hline Siklus 1 & 78,33 & - \\
\hline Siklus 2 & 82,00 & 3,67 \\
\hline
\end{tabular}

Dari data dalam Tabel 2 diatas, diperoleh temuan: a) pada siklus 1, rata-rata tingkat kemampuan guru dalam pelaksanaan pembelajaran mencapai 78,33. b) pada siklus 2, rata-rata kemampuan guru dalam pelaksanaan pembelajaran mencapai 82,00. Data ini menunjukkan Capaian ini menunjukkan peningkatan kemampuan guru dalam penyusunan RPP sebesar 3,67\%. 
Peningkatan Kemampuan Guru Dabin Gugus Putra Serang IV Wonosegoro - Boyolali dalam Memanfaatkan Lingkungan Sekolah Sebagai Sumber Belajar Melalui Diskusi Kelompok Kerja Guru (Parwanto)

Data pada tabel kemampuan guru dalam penyusunan RPP siklus 1 dan siklus 2 menunjukkan temuan rerata kemampuan guru dalam penyusunan RPP pada siklus 1 sebesar 78,80 dan siklus 2 sebesar 82,50. Temuan ini mengindikasikan adanya peningkatan tingkat tabel kemampuan guru dalam penyusunan RPP. Besaran peningkatan 3,70\%. Hal ini diartikan bahwa temuan siklus 1 dan 2 tersebut telah mencapai keberhasilan.

Keberhasilan penelitian ini bermakna bahwa guru mampu: 1) membuat RPP sekurang-kurangnya memuat Standar Kompetensi, Kompetensi Dasar, Indikator, alat/media, sumber belajar dan penilaian. 2) Kesesuaian antara materi pelajaran dengan media dan strategi pembelajaran. 3) Keterkaaitan antara materi pelajaran dengan pemilihan sumber belajar. 4) Kesesuaian antara tujuan pembelajaran dengan sumber bahan dan penilaian.

Data pada tabel 2 kemampuan guru dalam pelaksanaan pembelajaran siklus 1 dan siklus 2 menunjukkan temuan rerata kemampuan guru dalam pelaksanaan pembelajaran pada siklus 1 sebesar 78,33 dan siklus 2 sebesar 82,00. Temuan ini mengindikasikan adanya peningkatan tingkat tabel kemampuan guru dalam penyusunan RPP. Besaran peningkatan 3,67 \%. Hal ini diartikan bahwa temuan siklus 1 dan 2 tersebut telah mencapai keberhasilan.

Keberhasilan penelitian ini bermakna bahwa guru mampu: 1) melakukan kegiatan pendahuluan yaitu memberikan apersepsi dan motivasi ). 2) melakukan kegiatan inti pelaksanaan pembelajaran secara keseluruhan. 3) mengkaitkan materi pelajaran dengan lingkungan sekolah. 4) memberi contoh-contoh riil yang ada di lingkuan sekolah. 5) membuat evaluasi berkaitan dengan pemanfaatan lingkungan sekolah sebagai sumber belajar. 6) menutup pelajaran (memberi penguatan, memberi PR tentang pemanfaatan lingkungan sekolah).

Keampuhan strategi diskusi mampu meningkatkan kemampuan guru dalam memanfaatkan lingkungan sekolah sebagai sumber belajar. Keampuhan ini terbuktinya dalam sintak/langkah pembelajaran, 1) sintak satu membentuk kelompok. 2) sintak kedua memilih pemimpin kelompok. 3) sintak ketiga melakukan diskusi untuk menyusun RPP dan melakukan peer teaching. 4) sintak keempat mempresentasikan hasil pemecahan terbukti siswa mampu mengkomunikasikan hasil. 5) sintak kelima mengevaluasi proses pemecahan masalah terbukti siswa mampu mengkomunikasikan hasil.

\section{SIMPULAN}

Berdasarkan hasil penelitian dan pembahasan, dapat disimpulkan bahwa diskusi dapat meningkakan kemampuan guru dalam penyusunan RPP di Dabin Putra Serang IV, Kecamatan Wonosegoro, Kabupaten Boyolali sebesar 3,70\% sedangkan untuk kemampuan guru dalam pelaksanaan pembelajaran di Dabin Putra Serang IV, Kecamatan Wonosegoro, Kabupaten Boyolali meningkat sebesar 3,67\%. 
Setelah penelitian ini berhasil membuktikan bahwa diskusi kelompok Kerja Guru dapat meningkatkan kemampuan guru dalam memanfaatkan lingkungan sekolah sebagai sarana belajar maka peneliti memberikan saran, hendaknya guru dalam menyusun Rencana Pelaksanaan Pembelajaran ( RPP ) dapat memanfaatkan lingkungan sekolah sesuai dengan materi pembelajaran sebagai sumber belajar, Kepala Sekolah hendaknya mengajak, memotivasi, dan memfasilitasi kegiatan KKG di gugus sekolah masing-masing sehingga KKG benar-benar dapat dimanfaatkan sebagai forum ilmiah bagi para guru, pengawas sekolah hendaknya lebih aktif, dan kreatif dalam pendampingan, pembinaan, pembimbingan dan pelatihan professional terhadap guru dan kepala sekolah dalam kegiatan KKG yang terprogram dengan efisien, efektif, dan menyenangkan.

\section{DAFTAR PUSTAKA}

Badru Zaman, dkk. 2005. Media dan Sumber Belajar TK. Buku Materi Pokok PGTK 2304. Modul 1-9. Jakarta Universiats Terbuka.

Depdiknas. 2005. Undang-Undang Nomor 14 Tahun 2005 Tentang Sistem Pendidikan Nasional. Jakarta . Undang-Undang Nomor 14 Tahun 2005 Tentang Sistem Pendidikan Nasional. Jakarta

Dirjen peningkatan mutu pendidikan dan tenaga kependidikan. 2012. Pedoman pelaksanaan kinerja guru (PK Guru). Buku 2. Jakarta: kementerian Pendidikan dan Kebudayaan.

Ekowati, Endang. 2001. Stategi Pembelajaran Kooperatif. Modul Pelatihan Guru Terintegrasi Berbasis Kompetensi. Jakarta : Depdiknas.

Kasianto, I Wayan 2004 Meningkatkan Prestasi Belajar Peserta didik dengan Pendekatan Diskusi Kelompok. Laporan Penelitian Kelas. Tidak dipublikasikan

Peraturan Menteri Nomor 19 Tahun 2005 tentang Standar Pendidikan Nasional. Jakarta: Kemendikbud.

Rusyan Tabrani. 2001. Pendekatan dalam Proses Belajar Mengajar. Bandung Remaja Rosdakarya.

Sagala Syaiful. 2009. Administrasi Pendidikan Kontemporer. Bandung. Alfabeta

Sarman, Samsuni. 2005. Implementasi Pendekatan Works Based Learning pada Sumber Belajar Masyarakat dalam Pembelajaran PS-Ekonomi. Laporan Penelitian Tindakan Kelas. Banjarmasin. Tidak dipublikasikan. 